\title{
High impact of PGPR on biostatistic of Aphis craccivora (Hemiptera: Aphididae) on yardlong bean
}

\author{
HERMANU TRIWIDODO ${ }^{1, \varphi}$, LISTIHANI $^{2, v \varphi}$ \\ Department of Plant Protection, Faculty of Agriculture, Institut Pertanian Bogor. Jl. Meranti, Kampus IPB Darmaga, Bogor 16680, West Java, Indonesia. \\ Tel.: +62-251-8629354, Fax.: +62-251-8629352, `email: hermanutr@apps.ipb.ac.id, petanimerdeka@gmail.com \\ ${ }^{2}$ Department of Agrotechnology, Faculty of Agriculture, Universitas Mahasaraswati. Jl. Kamboja No. 11A, Denpasar 80233, Bali, Indonesia. \\ Tel.: +62-361-227019, ${ }^{\vee *}$ email: listihani9@gmail.com
}

Manuscript received: 18 May 2020. Revision accepted: 9 August 2020.

\begin{abstract}
Triwidodo H, Listihani. 2020. High impact of PGPR on biostatistic of Aphis craccivora (Hemiptera: Aphididae) on yardlong bean. Biodiversitas 21: 4016-4021. Plant growth-promoting rhizobacteria (PGPR) are root colonizing bacteria that live and develop near plant roots, which boost plant growth and act as antagonist agents. This research is aimed to asses the effect of PGPR on biostatistics of Aphis craccivora Koch on yardlong bean (Vigna unguiculata subsp. sesquipedalis). The research was conducted at WiSH Laboratory in Bogor, Indonesia, by tested PGPR mixture of Rhizobium, Bacillus polymyxa, and Pseudomonas fluorescens. The research discovered that the application with seed treatment and watered of PGPR affects the biology of Aphis craccivora in terms of lengthening its stadia of second instar nymph, lengthening its life cycle, and declining its fecundity. The application of PGPR also affects the biostatistics of Aphis craccivora. PGPR applied plants have a gross reproduction rate (GRR), net reproduction rate (Ro) and intrinsic increase rate (r) of Aphis craccivora that are lower than control. PGPR could slower the doubled time (DT) of Aphis craccivora to become lengthier than control. PGPR could improve plant growth: it could increase the number and length of roots, number of root nodules, plant height, number of leaves, as well as length and density of trichome.
\end{abstract}

Keywords: Induced resistance, intrinsic growth rate, life cycle, life table, physical structure, Rhizobium

\section{INTRODUCTION}

Plant growth-promoting rhizobacteria (PGPR) is used as an alternative to develop environment-friendly agriculture by decreasing the use of fertilizers and pesticides. Rhizobacteria are rhizosphere-competent bacteria that aggressively inhabiting plant roots; they are able to multiply and colonize on the roots (Muleta 2007). The bacterial genera such as Agrobacterium, Arthrobacter, Azotobacter, Azospirillum, Bacillus, Burkholderia, Caulobacter, Chromobacterium, Erwinia, Flavobacterium, Micrococcus, Pseudomonas and Serratia belongs to PGPR (Gray and Smith 2005).

PGPR induced resistance against insect pests through synthesis of phytohormones, increase in phosphorus and nitrogen uptake, and increase in iron and mineral solubility through chelation growth (Bowen and Rovira 1996). On tomato plants, PGPR application could induct the plant's resistance from pests since decreasing the consumption level of Bemisia tabaci (Shavit et al. 2013). At the harvesting, found that the average total yield of tomatoes treated with the PGPR significantly higher than that of the control and recorded a yield doubled compared to the control plants (Moustaine et al. 2017).

Induced plant resistance coule cause distruption on insect's feeding behavior and general life. The disturbed eating activity could affect pest's growth, development, fecundity, and mortality. Biostatistics are an basic 1 step in studying the growth of insect population. This research is aimed to understand the application of PGPR on yardlong bean (Vigna unguiculata subsp. sesquipedalis) and its effect on the biostatistics of Aphis craccivora Koch (Hemiptera: Aphididae).

\section{MATERIALS AND METHODS}

\section{Preparation of plant}

A number of 260 yardlong bean seeds cv. Bonaro were separated into two treatments treated: 130 seeds were soaked in PGPR suspension of Rhizomax trademark, meanwhile the other 130 seeds were soaked in aquadest as a control application. The PGPR suspension was made by mixing $10^{7} \mathrm{cfu} / \mathrm{L}$ of sterlizzed distilled water aquadest. The seeds were submerged in PGPR suspension and aquadest (control application) for 15 minutes and then dried on tissue paper for 15 minutes. Seeds were sownin 100 polybags which were filled with planting media: 60 polybags were used for observation on plant height, number of leaves and cohort maintenance of Aphis craccivora by sowing 3 seeds per polybag; and 40 polybags were used for observation on root parts and leaf trichome of yardlong bean by sowing 2 seeds per polybag. NPK fertilizer was added with a rate of 0.5 grams per polybag. The remaining PGPR suspension from the submersion process was watered to the PGPR-application planting media about $150 \mathrm{~mL}$ per polybag. Meanwhile, the control-application planting media were watered with water. The second watering process of PGPR-application plants with PGPR suspension and the second watering of 
control-application plants with water was done at the same time, which is 2 weeks after planting.

\section{Cohort maintenance of Aphis craccivora}

Two yardlong bean seeds were sown in each plastic cup filled with planting media. Yardlong bean seeds that are 7 days after planting were covered with insect confinement and on the next day were infested with two adults of $A$. craccivora per plastic cup, thus on the next day, a uniform age 1 st instar nymph of $A$. craccivora was obtained. The 1st instar nymph of $A$. craccivora in cohort population was infested on yardlong bean plant buds of both PGPRapplication and control-application plants when the plants are 30 days after planting, covered with insect confinement and based with black color carton paper. One bud from each polybag were taken, thus they were one 1st instar nymph of A. craccivora per polybag on both the PGPRapplication plants and the control-application plants.

\section{Observation on biology of Aphis craccivora}

Parameters observed were the time needed for each instar phase, life cycle, preoviposition, life span and fecundity of $A$. craccivora. The life cycle for A craccivora was observed from the time 1st instar nymph was infested on the yardlong bean buds until the time it became an adult. Preoviposition of A. craccivora was observed from the time needed since it became first adult to the time it delivered its 1 st instar nymph for the first time. The life span of A. craccivora begins from the first day it became an adult until the adult died. The observation of the fecundity of $A$. craccivora was counted from the number of nymph delivered by each adult during its life span. Data obtained from observation are shown in the biological table of $A$. craccivora.

\section{Life scale and biostatistics of Aphis craccivora}

The observation of life expectancy (lx) was done by counting the number of individual of $A$. craccivora that remain alive each day. Daily fecundity observation $(\mathrm{mx})$ is the average number of $A$. craccivora nymph that is deivered by each adult each day during age $(\mathrm{x})$. The life expectancy and daily fecundity data could be pictured in a curve shape, thus a life scale is obtained. A cohort life scale is a life scale which follows the cohort development from the 1st instar nymph until the last surviving adult. According to Birch (1948), the biostatistics parameters counted consist of:

$$
\begin{aligned}
& \text { Net reproduction rate }(\mathrm{Ro})=\sum 1 \mathrm{x} \cdot \mathrm{mx} \\
& \text { Gross reproduction rate }(\mathrm{GRR})=\sum \mathrm{mx} \\
& \text { Intrinsic increase rate }(\mathrm{r})=\sum 1 \mathrm{x} \cdot \mathrm{mx} \text { e-rx= } 1 \text {, with origin } \\
& \mathrm{r}=\ln (\mathrm{Ro}) / \mathrm{T} \\
& \text { Average generation time }(\mathrm{T})=\ln (\mathrm{Ro}) / \mathrm{r} \text {, with origin } \mathrm{T} \\
& =\sum \mathrm{x} .1 \mathrm{x} . \mathrm{mx} / \sum \mathrm{x} \cdot \mathrm{mx} \\
& \text { Doubling time }(\mathrm{DT})=\ln (2) / \mathrm{r}
\end{aligned}
$$

Net reproduction rate (Ro) is the number of a female individual that would be produced by each female adult in the population. According to Price (1997), intrinsic increase rate $(r)$ is a population increase rate with an unlimited resource. Average generation time $(\mathrm{T})$ is the average time needed from a nymph is laid until the female adult produces half of its descendants. Doubled population (DT) is the time needed for A. craccivora to multiply itself. A variety prediction procedure is conducted through the jackknife method.

\section{Physical structure observation of yardlong bean}

The variables observed consist of the length and number of roots, number of root nodules, plant height, number of leaves, length, and density of leaf trichome. The observation was conducted each week for one month. The observation of plant height and number of leaves were conducted on plants that would be used in A. craccivora cohort maintenance. The observation on the number of roots was done by counting the number of primary and secondary roots of each plant. Trichome observation was done by taking sample of one leaf located the third from the bottom part of each plant, having it measured $1 \times 1 \mathrm{~cm}^{2}$ and then observed. Temperature was measured and recorded at daily basis.

\section{RESULTS AND DISCUSSION}

Indirect effect of PGPR application to aphid caused the length of 2nd instar nymph stadia to become lengthy (Table 1). PGPR application did not have a significant effect to the length of 1 st, $3 \mathrm{rd}$ and 4 th instar stadia of A. craccivora if compared to those of the untreated plants.

During the 1st instar, aphid was in the dwelling searching phase and not yet active searching for food because nutrition received from its parent was still sufficient for its life. At the time of 2 nd instar, aphid is in the plant fluid suction adaptation phase, allowing PGPR application to have a significant effect. At the time of the 3rd and 4th instar, aphid has already adapted to its environment and food, thus PGPR application does not have a significant effect.

Table 1. Biology of Aphis craccivora on yardlong bean without PGPR application (control) and with PGPR application

\begin{tabular}{lcc}
\hline \multirow{2}{*}{ Stadia } & Control (days) & PGPR (days) \\
\cline { 2 - 3 } & $(\overline{\mathbf{x}} \pm \mathbf{S E})$ & $(\overline{\mathbf{x}} \pm \mathbf{S E})$ \\
\hline 1st Instar & $1.115 \pm 0.064 \mathrm{a}$ & $1.250 \pm 0.090 \mathrm{a}$ \\
2nd Instar & $1.154 \pm 0.072 \mathrm{a}$ & $1.625 \pm 0.118 \mathrm{~b}$ \\
3rd Instar & $1.000 \pm 0.000 \mathrm{a}$ & $1.083 \pm 0.058 \mathrm{a}$ \\
4th Instar & $1.038 \pm 0.038 \mathrm{a}$ & $1.083 \pm 0.058 \mathrm{a}$ \\
Life cycle & $4.308 \pm 0.092 \mathrm{a}$ & $5.042 \pm 0.095 \mathrm{~b}$ \\
Preoviposition & $0.500 \pm 0.100 \mathrm{a}$ & $0.500 \pm 0.104 \mathrm{a}$ \\
Life span & $15.420 \pm 1.130 \mathrm{a}$ & $12.630 \pm 1.140 \mathrm{a}$ \\
& Control (eggs) & PGPR (eggs) \\
& $(\overline{\mathrm{x}} \pm$ SE) & $(\overline{\mathrm{x}} \pm \mathrm{SE})$
\end{tabular}

Fecundity $104.420 \pm 9.290 \mathrm{a}$ $69.460 \pm 6.880 \mathrm{~b}$

Note: Numbers on the same line that are followed by the same letter indicates does not significantly different based on $\mathrm{t}$ test, $\alpha=$ 0.05 . 
PGPR application was able to increase the length and number of roots of yardlong bean (Table 2). This is caused by the second PGPR application done at the time the plant is 2 weeks after planting, making the number of PGPR colonized in the roots increase. The increase in length and number of roots will increase the absorption of nutrient (Fageria and Moreira 2011). According to Sheirdill et al. (2019), PGPR is capable of increasing the length of roots, thus the growth of plant become faster and production increases.

PGPR application on yardlong bean with Rhizobium could increase the number of root nodules compared to the number of root nodules on control-application plants (Table 3). Rhizobium is a root bacterium that fixates nitrogen. The increase of nitrogen, which is marked by the increase in the number of root nodules, does not make the plants vulnerable to pests and diseases because Rhizobium produces phytohormone, siderophore, and 1aminocyclopropane-1-carboxylate deaminase that could increase plants' resistance (Tuhuteru et al. 2019). Based on research conducted by Yang et al. (2009), Rhizobium and Pseudomonas fluorescens application on yardlong bean could increase plants' productivity, which could be seen from the increasing number of root nodules.

Yardlong bean with PGPR application has significant height difference compared to that of the controlapplication plants, but plants with age 3 weeks after planting do not have significant height difference (Table 4). Besides, the numbers of leaves on PGPR-application plants differ significantly at the time the plants are 4 weeks after planting. PGPR application could increase plant growth because it helps increase the production of phytohormone, such as IAA, gibberellin, and cytokinin (Bhattacharyya and Jha 2012). Application of PGPR strains had significant effects on $\mathrm{K}, \mathrm{Ca}, \mathrm{Mg}, \mathrm{Fe}, \mathrm{Mn}$, and $\mathrm{Zn}$ contents in soil (Orhan et al. 2006). The increase in the number of leaves is usually followed by an increasing number of attacking pests because the population of pests would increase with the food available. This differs from the research conducted by Pineda et al. (2013) which states that the increase in the number of Arabidopsis thaliana leaves does not increase the population of Myzus persicae because plants do not have resistance to pests.

On PGPR-treated yardlong bean, a significant increase in length and density of leaf trichome were found on plants 2 weeks after planting (Table 5). Since causing $A$. craccivora difficult to suck nutrition from a plant's cell, the longer and denser leaf trichome after PGPR application could disturb insects' eating activity (Hanley et al. 2007). The increase of plant resistance after PGPR application could be seen from the increase of length and density of trichome, harming the biostatistics of A. craccivora. The increase of length and density of trichome shows that PGPR could be used as a biocontrol agent in pressing the growth of plant pests. Based on research conducted by Sulistyo (2011), the increase in the number of trichomes has a significant negative correlation to the population of Bemisia tabaci and leaf defect intensity but has a positive correlation with result increase per hectare.

Table 3. Effect of PGPR application on the number of root nodules on yardlong bean

\begin{tabular}{|c|c|c|}
\hline \multirow{3}{*}{$\begin{array}{c}\text { Age } \\
\text { (weeks after } \\
\text { planting) } \\
\end{array}$} & \multicolumn{2}{|c|}{ Number of root nodules } \\
\hline & Control & PGPR \\
\hline & $(\overline{\mathbf{x}} \pm \mathrm{SE})$ & $(\overline{\mathbf{x}} \pm \mathrm{SE})$ \\
\hline 2 & $18.22 \pm 5.93 a$ & $29.00 \pm 7.47 b$ \\
\hline 3 & $36.14 \pm 9.01 \mathrm{a}$ & $115.75 \pm 27.63 b$ \\
\hline 4 & $94.90 \pm 27.20 \mathrm{a}$ & $258.70 \pm 25.80 \mathrm{~b}$ \\
\hline
\end{tabular}

Note: Numbers on the same line that are followed by the same letter indicate does not significantly different based on t-test, $\alpha=$ 0.05 .

Table 2. Effect of PGPR application on the length and number of roots on yardlong bean

\begin{tabular}{|c|c|c|c|c|}
\hline \multirow{3}{*}{$\begin{array}{c}\text { Age } \\
\text { (weeks after planting) }\end{array}$} & \multicolumn{2}{|c|}{ Root length (cm) } & \multicolumn{2}{|c|}{ Number of roots } \\
\hline & Control & PGPR & Control & PGPR \\
\hline & $(\overline{\mathrm{x}} \pm \mathrm{SE})$ & $(\overline{\mathrm{x}} \pm \mathrm{SE})$ & $(\overline{\mathbf{x}} \pm \mathrm{SE})$ & $(\overline{\mathrm{x}} \pm \mathrm{SE})$ \\
\hline 1 & $10.02 \pm 3.71 \mathrm{a}$ & $13.01 \pm 3.31 \mathrm{a}$ & $26.44 \pm 9.44 a$ & $39.78 \pm 11.36 \mathrm{~b}$ \\
\hline 2 & $14.79 \pm 3.93 \mathrm{a}$ & $20.16 \pm 4.02 b$ & $45.44 \pm 12.19 a$ & $81.30 \pm 12.50 \mathrm{~b}$ \\
\hline 3 & $20.36 \pm 4.97 a$ & $56.63 \pm 13.69 b$ & $48.00 \pm 16.10 \mathrm{a}$ & $172.10 \pm 66.10 \mathrm{~b}$ \\
\hline 4 & $29.27 \pm 6.66 a$ & $69.89 \pm 5.52 b$ & $77.14 \pm 14.62 \mathrm{a}$ & $281.10 \pm 61.26 b$ \\
\hline
\end{tabular}

Note: Numbers on the same line that are followed by the same letter indicate does not significantly different based on t-test, $\alpha=0.05$.

Table 4. The effect of PGPR application on plant height and number of leaves of yardlong bean

\begin{tabular}{ccccc}
\hline $\begin{array}{c}\text { Age } \\
\text { (weeks after sowing) }\end{array}$ & \multicolumn{2}{c}{ Plant height } & \multicolumn{2}{c}{ Number of leaves } \\
\cline { 2 - 5 } Control $^{\mathbf{a}}$ & $11.678 \pm 2.143 \mathrm{a}$ & $12.743 \pm 1.581 \mathrm{~b}$ & $0.000 \pm 0.000 \mathrm{a}$ & $0.014 \pm 0.118 \mathrm{a}$ \\
PGPR $^{\mathbf{a}}$ & $41.924 \pm 6.127 \mathrm{~b}$ & $1.963 \pm 0.190 \mathrm{a}$ & $2.014 \pm 0.316 \mathrm{a}$ \\
3 & $40.130 \pm 4.945 \mathrm{a}$ & $82.690 \pm 19.580 \mathrm{a}$ & $4.049 \pm 0.687 \mathrm{a}$ & $4.296 \pm 1.113 \mathrm{a}$ \\
4 & $79.860 \pm 17.260 \mathrm{a}$ & $129.310 \pm 24.610 \mathrm{~b}$ & $6.309 \pm 0.996 \mathrm{a}$ & $7.408 \pm 1.961 \mathrm{~b}$ \\
\hline
\end{tabular}

Note: Numbers on the same line that are followed by the same letter indicate does not significantly different based on t-test, $\alpha=0.05$. 
Table 5. The effect of PGPR application on leaf trichome length and density on yardlong bean

\begin{tabular}{|c|c|c|c|c|}
\hline \multirow{3}{*}{$\begin{array}{c}\text { Age } \\
\text { (week after planting) }\end{array}$} & \multicolumn{2}{|c|}{ Leaf trichome length } & \multicolumn{2}{|c|}{ Leaf trichome density } \\
\hline & Control & PGPR & Control & PGPR \\
\hline & $(\overline{\mathbf{x}} \pm \mathrm{SE})$ & $(\overline{\mathrm{x}} \pm \mathrm{SE})$ & $(\overline{\mathbf{x}} \pm \mathrm{SE})$ & $(\overline{\mathbf{x}} \pm \mathrm{SE})$ \\
\hline 1 & $0.000 \pm 0.000 \mathrm{a}$ & $0.009 \pm 0.015 \mathrm{a}$ & $0.000 \pm 0.000 \mathrm{a}$ & $1.222 \pm 1.856 \mathrm{a}$ \\
\hline 2 & $0.027 \pm 0.005 a$ & $0.039 \pm 0.003 b$ & $18.380 \pm 7.580 \mathrm{a}$ & $43.330 \pm 8.940 \mathrm{~b}$ \\
\hline 3 & $0.031 \pm 0.002 \mathrm{a}$ & $0.045 \pm 0.012 b$ & $20.290 \pm 7.500 \mathrm{a}$ & $70.140 \pm 17.57 b$ \\
\hline 4 & $0.049 \pm 0.008 \mathrm{a}$ & $0.063 \pm 0.012 b$ & $43.290 \pm 9.660 \mathrm{a}$ & $207.800 \pm 50.20 \mathrm{~b}$ \\
\hline
\end{tabular}

Note: Numbers on the same line that are followed by the same letter indicates does not significantly different based on $\mathrm{t}$ test, $\alpha=0.05$

Aphis craccivora on PGPR- treated plants have a slower life cycle if compared to that of the untreated plants. The slow life cycle of $A$. craccivora on PGPR-application plants is proportional to its lag on reproduction time. Lagged reproduction time could decrease the reproduction rate. Reproduction rate is one of the factors that determine A. craccivora to increase its colony. According to Li et al. (2005), the lag of reproduction time could increase insects' mortality.

Preoviposition of A. craccivora on PGPR-application plants does not have a significant effect, but the preoviposition on PGPR-application plants is slightly longer compared to preoviposition on control-application plants. The lagged preoviposition of A. craccivora is caused by the increase of density and length of trichome on the leaves of PGPR-application yardlong bean. Trichome density negatively affects the ovipositional behavior, feeding, and larval nutrition of insect pests (Hanley et al 2005). In addition, dense trichome affects the herbivory mechanically and interferes with movement of insects (Agrawal et al. 2009).

Life span of A. craccivora on PGPR-application plants is shorter compared to that of control-application plants. Life expectancy of $A$. craccivora is influenced by the amount of nutrition obtained for its life continuity. Plants' increasing resistance to PGPR application caused $A$. craccivora difficult to obtain nutrition, thus the mortality rate of A. craccivora is higher compared to that of control. Antagonist relationship between plant and aphid with PGPR application could increase aphid selection (TetardJones et al. 2012).

Fecundity of A. craccivora on PGPR-application plants was lowers compared to that of untreated plants (Table 1). Insect reproduction is influenced by the protein content that is obtained. It is thought that the protein absorbed by $A$. craccivora after PGPR application was not able to fulfill $A$. craccivora's nutrition need. PGPR application causes $A$. craccivora lack of nutrition, thus decreasing its reproduction ability. Use of both PGPR strains was very useful for control of aphid population. Indeed, the PGPR increases the accumulation of phenolic compounds and phytoalexins, transcripts, and pathogenesis-related protein (Meena et al. 2000).
The survival type of $A$. craccivora shows curve type 2 on control-application plants and curve type 1 on PGPRapplication plants (Figure 1). According to Price (1997), curve type 1 showed low population mortality in young ages and high population mortality in old ages, curve type 2 showed constant population mortality of an individual, and curve type 3 showed high population mortality at young ages. The duration of this process has an important role in the development of a population. Population with high individual mortality during old age would have a different structure from the population with high mortality during pre-adult period. High individual mortality during pre-adult period would have a lower population in the next generation compared with high mortality during adult period.

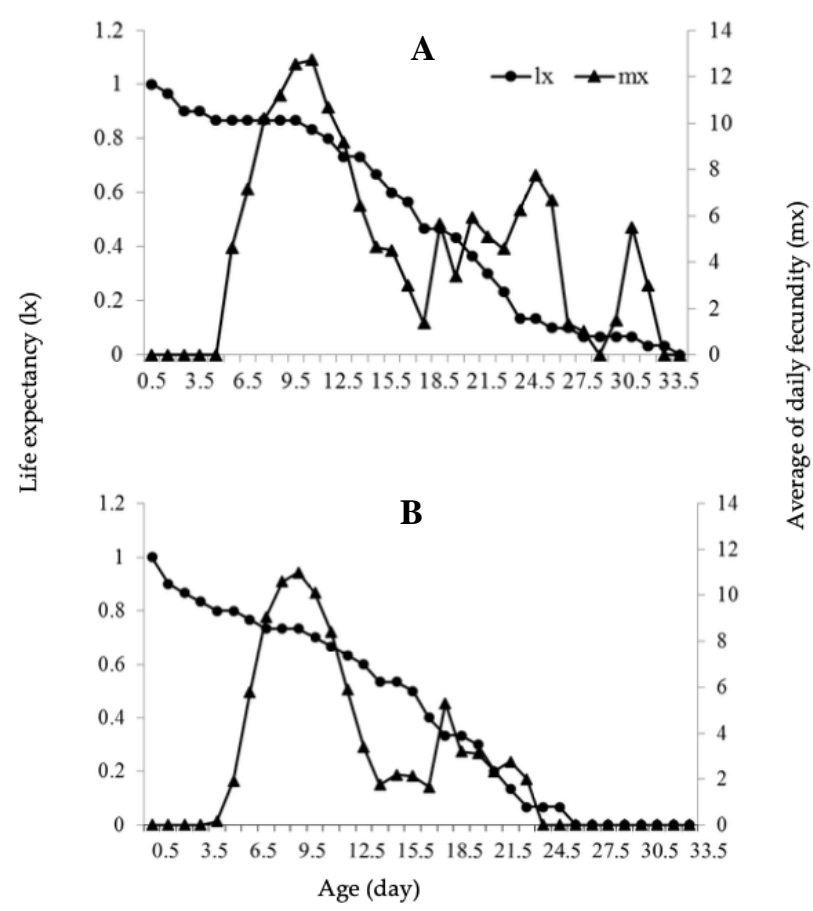

Figure 1. Life expectancy and daily fecundity of Aphis craccivora on yardlong bean with untreated plants (A) PGPRtreated plants $(\mathrm{B})$ 
Table 6. Biostatistics of Aphis craccivora on yardlong bean without PGPR application (control) and with PGPR application

\begin{tabular}{lcc}
\hline \multicolumn{1}{c}{ Parameter } & Control & PGPR \\
\cline { 2 - 3 } & $(\overline{\mathbf{x}} \pm$ SE) & $(\overline{\mathbf{x}} \pm$ SE $)$ \\
\hline Gross reproduction rate (GRR) & $151.256 \pm 1.324 \mathrm{a}$ & $89.279 \pm 1.415 \mathrm{~b}$ \\
Net reproduction rate (Ro) & $89.838 \pm 1.165 \mathrm{a}$ & $53.509 \pm 1.057 \mathrm{~b}$ \\
Intrinsic increase rate (r) & $0.501 \pm 0.003 \mathrm{a}$ & $0.446 \pm 0.004 \mathrm{~b}$ \\
Generation time average (T) & $8.929 \pm 0.051 \mathrm{a}$ & $8.921 \pm 0.058 \mathrm{a}$ \\
Doubling time (DT) & $1.383 \pm 0.009 \mathrm{a}$ & $1.554 \pm 0.014 \mathrm{~b}$ \\
\hline
\end{tabular}

Note: Numbers on the same line that are followed by the same letter indicates does not significantly different based on t-test, $\alpha=$ 0.05

The average number of nymph born by every $A$. craccivora adult each day on the PGPR-application plants was different compared to that of the control-application plants (Figure 1). The highest daily fecundity on controlapplication plants could reach 13 nymphs, meanwhile on PGPR application only reached 11 nymphs. The highest $A$. craccivora fecundity on control-application plants is 5 times, meanwhile on PGPR-application plants is only 3 times. A. craccivora does not produce nymphs on controlapplication plants during 28.5-29.5 days age because it needs time to fulfill its nutrition to be able to reproduce again. The shape of $A$. craccivora fecundity curve of PGPR-application plants depicts the lower fecundity than control-application plants.

The value of GRR and Ro of A. craccivora are larger on control-application plants compared to that on PGPRapplication plants (Table 6). The value of Ro on controlapplication plants shows that the next generation of $A$. craccivora would increase as many as $89.838 \pm 1.165$ times compared to its previous generation. Meanwhile, Ro on PGPR-treated plants s only increase as many as 53.509 \pm 1.057 times compared to its previous generation. Ro value indicates the level of compatibility between insect and host plants. The higher the Ro and GRR values, the higher the level of insect compatibility to the host plant (Hutasoit et al. 2020). PGPR application provides s detrimental effect to A. craccivora life since it decreases its reproduction rate. The decrease in reproduction rate could cause a decrease in insect population in the next generation.

The value $r$ is defined from the life cycle, birth, and mortality of $A$. craccivora. Long life cycle on PGPRapplication plants causes its intrinsic increase rate decrease (Table 6). Intrinsic increase rate can be used to predict insect population growth in long term. The $\mathrm{r}$ value of $A$. craccivora on PGPR-application plants is lower than that on control-application plants. The value of $r$ on controlapplication plants range between $0.501 \pm 0.003$ nymphs per day, meanwhile on PGPR-treated plants range between $0.446 \pm 0.004$ nymphs per day Low intrinsic increase rate could be interpreted that a population of an organism has a low chance to keep growing. This positively in line with the research conducted by Lee et al. (2012) which stated that PGPR application could decrease intrinsic increase rate of Myzus persicae because of the increase of plant resistance induction.
Species in a population with lower $\mathrm{T}$ value will grow faster compared to species with high $\mathrm{T}$ value (Hutasoit et al. 2020 ). The result shows that half descendants produced by A. craccivora on PGPR-treated plants have shorter generation time compared to that of control-application plants. This means on PGPR treated plants, population of A. craccivora grows faster than in control-application plants. Despite that, host's suitability is not only illustrated from $T$ value, since the GRR, Ro, $r$, and DT values are also influential.

Time needed for A. craccivora to double (DT) is 1.383 \pm 0.009 days on untreated plants and $1.554 \pm 0.014$ days on PGPR-application plants (Table 6). Low DT value could increase gross reproduction rate (GRR) and net reproduction rate $(\mathrm{Ro})$ at a particular time (Efendi et al. 2018. The decrease of $A$. craccivora fecundity affected a long period to double its population and decrease its intrinsic increase rate. Insects with faster DT would accelerate the decrease in food resources (Birch 1948).

\section{ACKNOWLEDGEMENTS}

We would like to thank CV WiSH Indonesia for providing us with experimental facilities and laboratories during the research.

\section{REFERENCES}

Agrawal AA, Fishbien M, Jetter R, Salminen JP, Goldstein JB, Greitag AE, Sparks JP. 2009. Phylogenetic ecology of leaf surface traits in the milkweeds (Asclepias spp.): Chemistry, ecophysiology, and insect behavior. New Phytol 183 (3): 848-867. DOI: 10.1111/j.14698137.2009.02897.x

Bhattacharyya PN, Jha DK. 2012. Plant growth-promoting rhizobacteria (PGPR): emergence in agriculture. World J Microbiol Biotechnol 28: 1327-1350. DOI: 10.1007/s11274-011-0979-9

Birch L. 1948. The intrinsic rate of natural increase of an insect population. J Anim Ecol 17: 15-26.

Bowen GD, Rovira AD. 1996. The rhizosphere and its management to improve plant growth. J Adv Agronom 66: 1-102.

Efendi S, Yaherwandi, Nelly N. 2018. Biology and demographic statistics of Coccinella transversalis Thunberg (Coleoptera: Coccinellidae), predator Aphis gossypii Glover (Homoptera: Aphididae). Jurnal Perlindungan Tanaman Indonesia 22 (1): 91-97. [Indonesian]

Fageria NK, Moreire A. 2011. The role of mineral nutrition on root growth of crop plants. J Adv Agronom 110: 251-331

Gray EJ, Smith DL. 2005. Intracellular and extracellular PGPR: Commonalities and distinctions in the plant-bacterium signalling processes. J Soil Biol Biochem 37 (3): 395-412. DOI: 10.1016/j.soilbio.2004.08.030

Hutasoit RT, Kalqutny SH, Widiarta IN. 2020. Spatial distribution pattern, bionomic, and demographic parameters of a new invasive species of armyworm Spodoptera frugiferda (Lepidoptera; Noctuidae) in maize of South Sumatra, Indonesia. Biodiversitas 21 (8): 35763582

Lee B, Lee S, Ryu CM. 2012. Foliar aphid feeding recruits rhizosphere bacteria and primes plant immunity against pathogenic and nonpathogenic bacteria in pepper. Ann Bot 110 (2): 281-290. DOI: 10.1093/aob/mcs055

Li B, Xie Gl, Soad A, Coosemans J. 2005. Suppression of Meloidogyne javanica by antagonistic and plant growth-promoting rhizobacteria. J Zhejiang Univ Sci B 6 (6): 496-501. DOI: 10.1631/jzus.2005.B0496

Meena B, Radhajeyalakshmi R, Marimuthu T, Vidhyasekaran P, Doraiswamy S, Velazhahan R. 2000. Induction of pathogenesisrelated proteins, phenolics, and phenylalanine ammonia-lyse in 
groundnut by Pseudomonas fluorescens. Plant Dis Prot 107 (5): 514 527.

Moustaine M, Elkahkahi R, Benbouazza A, Benkirane R, Achbani E 2017. Effect of plant growth-promoting rhizobacterial (PGPR) inoculation on growth in tomato (Solanum lycopersicum L.) and characterization for direct PGP abilities in Morocco. Intl $\mathrm{J}$ Environ Agric Biotechnol 2 (2): 590-596. DOI: $10.22161 /$ ijeab/2.2.5

Muleta D. 2007. Microbial inputs in coffee (Coffea arabica L.) production systems, Southwestern Ethiopia [Dissertation]. Swedish University of Agricultural Sciences, Sweden.

Orhan E, Esitken A, Ercisli S, Turan M, Sahin F. 2006. Effects of plant growth-promoting rhizobacteria (PGPR) on yield, growth and nutrient contents in organically growing raspberry. Sci Hortic 111: 38-43. DOI: $10.1016 /$ j.scienta.2006.09.002

Pineda A, Soler R, Weldegergis BT, Shimwela MM, Van Loon JJ, Dicke M. 2013. Non-pathogenic rhizobacteria interfere with the attraction of parasitoids to aphid-induced plant volatiles via jasmonic acid signalling. Plant Cell Environ 36 (2): 393-404. DOI: 10.1111/j.13653040.2012.02581.x.
Price PW. 1997. Insect Ecology, 3rd ed. John Wiley \& Sons, New York. Shavit R, Ofek-Lalzar M, Burdman S, Morin S. 2013. Inoculation of tomato plants with rhizobacteria enhances the performance of the phloem-feeding insect Bemisia tabaci. Front Plant Sci 4: 306. DOI: 10.3389/fpls.2013.00306.

Sheirdill RA, Hayat R, Zhang X, Abbasi NA, Ali S, Ahmed M, Khattak JMK, Ahmad S. 2019. Exploring potential soil bacteria for sustainable wheat (Triticum aestivum L.) production. Sustainability 11: 3361. DOI: $10.3390 / \mathrm{su} 11123361$

Tetard-Jones C, Kertesz MA, Preziosi RF. 2012. Identification of plant quantitative trait loci modulating a rhizobacteria-aphid indirect effect. PLoS One 7 (7): e41524. DOI: 10.1371/journal.pone.0041524

Tuhuteru S, Sulistyaningsih E, Wibowo A. 2019. Aplikasi plant growth promoting rhizobacteria dalam meningkatkan produktivitas bawang merah di lahan pasir pantai. Jurnal Agron Indonesia 47 (1): 53-60. [Indonesian]

Yang J, Kloepper JW, Ryu CM. 2009. Rhizosphere bacteria help plants tolerate abiotic stress. Trends Plant Sci 14 (1): 1-4. DOI: 10.1016/j.tplants.2008.10.004. 